A-rkivoc

Free to Authors and Readers
A Platinum Open Access Journal

for Organic Chemistry

Paper

DOAJ Seal

Arkivoc 2021, part viii, 13-22

\title{
Synthesis and characterization of new $\beta-D-C$-glycosides analogous to curcuminoids
}

\author{
Eugenio Torres-Rodríguez, ${ }^{* a}$ Quirino Arias Cedeño, ${ }^{a}$ Dirk Michalik, ${ }^{b}$ Rodisnel Perdomo Rivera, ${ }^{a}$ \\ and Christian Vogel ${ }^{b}$ \\ a Center of Studies for Applied Chemistry. University of Granma. Cuba \\ ${ }^{b}$ Institute of Chemistry. University of Rostock. Germany \\ Email: etorresrodriguez@udg.co.cu
}

Dedicated to Prof. Peter Langer for his outstanding contribution to the training of Cuban organic chemists

Received 09-25-2020

Accepted 01-09-2021

Published on line 02-08-2021

\section{Abstract}

The synthesis of two new $\beta$ - $C$-glycosides with potential biological activity is described. In the first reaction step, the $C$-glycoside was obtained starting from tetra-O-benzyl-mannosyl trichloroacetimidate and 2-(1,3dioxan-2-yl)phenol. In mannosylation reaction the protection of the aldehyde group in the phenolic compound is essential, thus guaranteeing a high electron density on the acceptor. In a second stage, the aldehyde group in the aglycone is released and finally the condensation is carried out with acetone or acetylacetone to obtain the corresponding curcuminoid-like $C$-mannosides with yields of 30 and $36 \%$ respectively. The NMR data show that both compounds exist in their $\beta$ form.

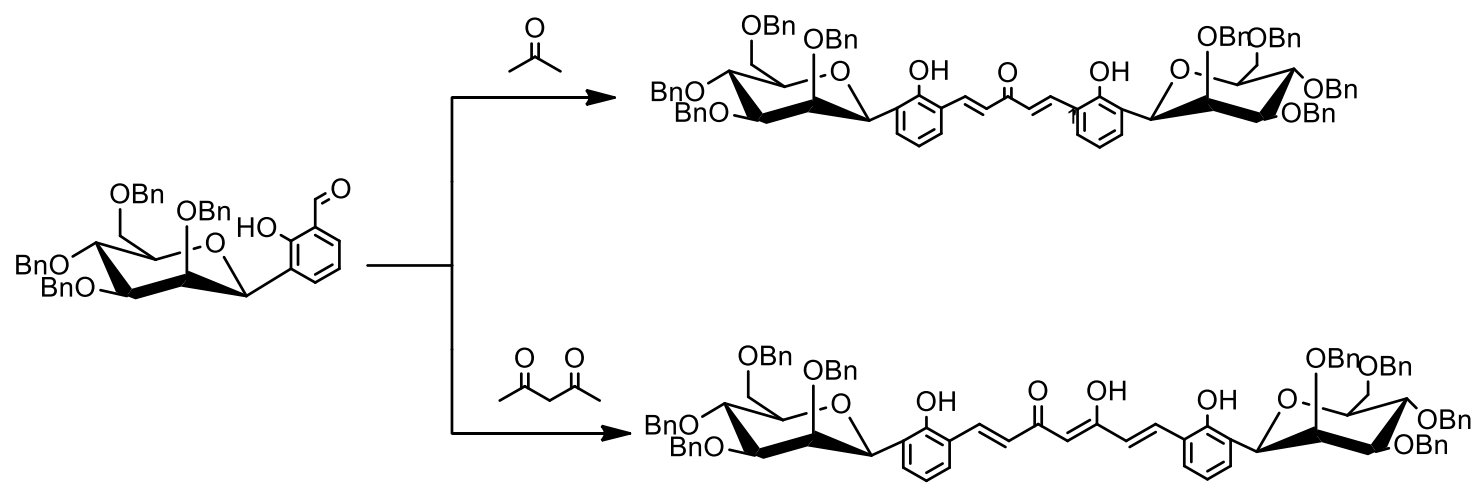

Keywords: curcuminoids, condensation, $C$-glycosylation, $\beta$ - $C$-glycosides 


\section{Introduction}

Among the secondary metabolites isolated from plants with greater structural analogy to curcumin are chalcones ( $\alpha, \beta$-unsaturated ketones), which is why many authors include them within curcuminoids. ${ }^{1}$ This family of compounds has a wide variety of biological activity among which its use as anti-inflammatory, antipyretic, analgesic, bactericidal, antifungal, insecticidal and antioxidant are highlighted. ${ }^{2-4}$ One of the practical problems in the use of these compounds is their low solubility in most common solvents and even more so in biological fluids, which limits their absorption. The binding of curcuminoids to other molecules such as carbohydrates could be a solution to this problem. Glycosides with an aromatic or heteroaromatic aglycone have been isolated from natural sources and many of them exhibit potent antibacterial and antiproliferative activity. ${ }^{5}$

The Friedel-Crafts reaction between a glycosyl donor and aromatic compounds with high electron density is used for the biosynthesis of $C$-glycosides. ${ }^{6}$ The replacement of the C-O bond in the anomeric center with a C$\mathrm{C}$ bond provides greater stability to the glycoside with respect to hydrolysis, which gives it attractive pharmacological applications because it is more resistant to degradation in vivo. ${ }^{7}$

Various catalysts such as $\mathrm{BF}_{3} \cdot \mathrm{OEt}_{2}, \mathrm{ZnCl}_{2}$ and trimethylsilyl trifluoromethanesulfonate (TMSOTf) have been used in C-glycosylation. 8,9 In 2010 Opatz and collaborators performed the mannosylation of phenolic compounds with high electron density, these authors demonstrated the $\beta$-selectivity of this reaction when tetra-O-benzyl-mannosyl trichloroacetimidate was used as glycosyl donor and TMSOTf as promoter, achieving yields ranging from $45-66 \% .^{10}$

This paper describes the obtaining of two new $C$-glycosides in which aglycones are curcuminoids and sugar is mannose. The synthetic procedure used allowed both compounds to be obtained in their $\beta$-form, which gives it great biological potential. $5,11,12$

\section{Results and Discussion}

\section{Synthesis of raw materials}

The starting materials 2-(1,3-dioxan-2-yl) phenol and tetra-O-benzyl-D-mannosyl trichloroacetimidate are known substances and were prepared according to reported procedures. ${ }^{13-15}$

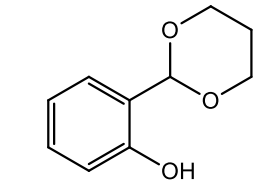

2-(1,3-dioxan-2-yl)phenol

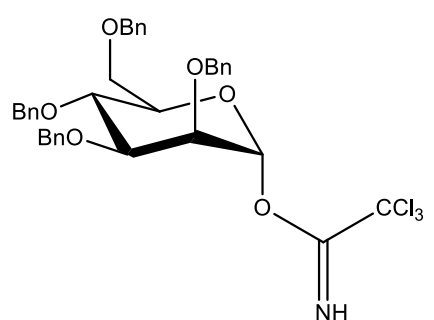

tetra-O-benzyl-D-mannopyranosyl-trichloroacetimidate

Figure 1. Starting materials.

C-glycosylation was performed based on the procedure reported by Opatz et al. ${ }^{10}$ Tetra-O-benzylmannosyl trichloroacetimidate was used as a glycosyl donor and 2-(1,3-dioxan-2-yl) phenol as an acceptor. 
Dichloromethane (DCM) was used as solvent and TMSOTf as promoter, the mixture was stirred at $0{ }^{\circ} \mathrm{C}$ under an argon atmosphere for three hours.

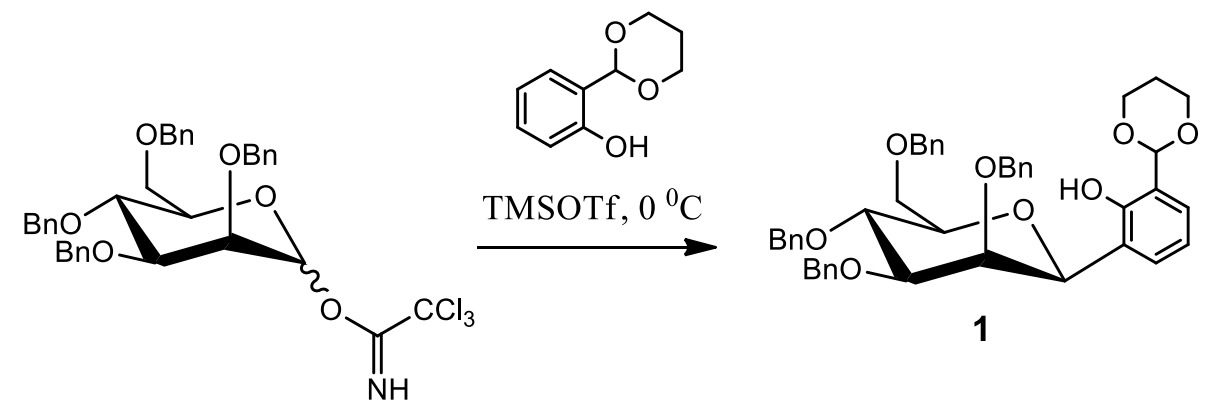

Scheme 1. C-glycosylation of tetra-O-benzyl-mannosyl trichloroacetimidate.

The use of mannose as glycosyl donor is due to the results reported by Li et al., ${ }^{16}$ who performed the C-glycosylation of a large variety of phenols with perbenzylated glucose, galactose and mannose trifluoroacetimidates. These authors achieved the highest yields when they used mannose as a glycosyl donor.

In ortho- $\mathrm{C}$-glycosylation of phenols with high electron density, $\mathrm{O}$-glycoside formation first occurs followed by an $\mathrm{O} / \mathrm{C}$ rearrangement induced by a Lewis acid. ${ }^{7,8,10,16,17} \mathrm{~A}$ high $\beta$-selectivity was observed for glucose and galactose ${ }^{16,17}$ in our case, the same results were obtained when using mannose.

In the ${ }^{1} \mathrm{H}-\mathrm{NMR}$ spectrum of the compound (1) a singlet appears at $10.06 \mathrm{ppm}$ corresponding to the only hydroxyl proton in the molecule. The unequivocal assignment of this signal was carried out through experiments of exchange of labile protons with deuterium by means of deuterated water. The disappearance of the signal confirmed the assignment to the hydroxyl proton. At 7.40; 7.65 and $6.87 \mathrm{ppm}$ are observed three signals corresponding to the aromatic protons (3) from aglycone. A multiplet corresponding to the 20 aromatic protons of the four benzyl groups from mannose appears in the interval $6.94-7.24$ ppm. At 5.41 ppm appears the $\mathrm{H}-1^{\prime}$ proton signal of the pyranose ring from sugar, the $\mathrm{H}-1^{\prime} / \mathrm{H}-2^{\prime}$ coupling with ${ }^{3} J_{1^{\prime}, 2^{\prime}}=2.1 \mathrm{~Hz}$, evidence that this proton $\left(\mathrm{H}-\mathrm{1}^{\prime}\right)$ is in $\alpha$ position and therefore the aglycone is in $\beta$ position. ${ }^{18}$ These results were confirmed by NOESY and correspond to those reported by Opatz et al., ${ }^{10}$ who achieved $\beta$-selectivity in the ortho- $C$ mannosylation of electron-rich phenols. The structural characteristics and interaction a-e of protons $\mathrm{H} 1$ and $\mathrm{H}-$ 2 are shown in Figure 2.

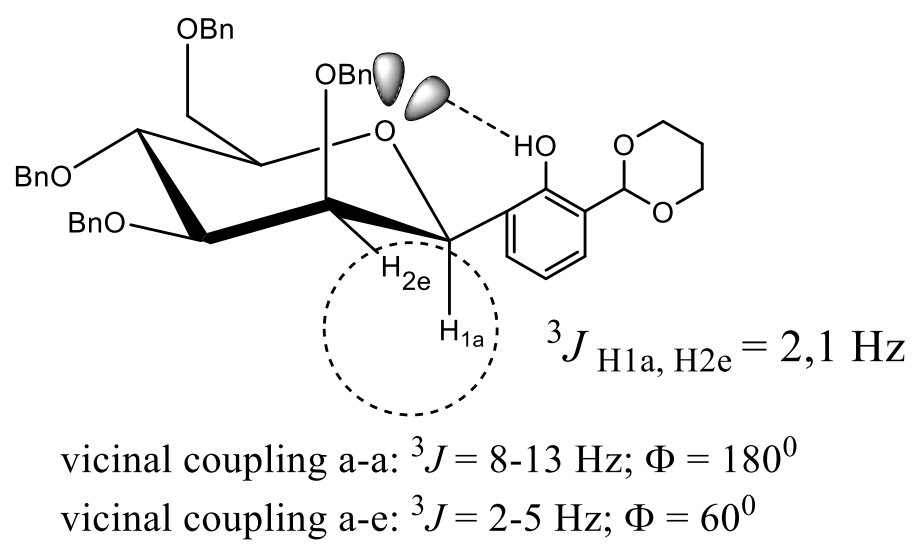

Figure 2. Ha-He vicinal coupling with ${ }^{3} J_{1^{\prime}, 2^{\prime}}=2.1 \mathrm{~Hz}$. 
In addition, five signals were recorded at $3.64 ; 4.46 ; 4.55 ; 4.63$ and $4.79 \mathrm{ppm}$, the first of them corresponding to the $\mathrm{H}-\mathrm{6}^{\prime}$ of the pyranose structure and the remaining signals which were assigned to the four methylenes from the benzyl groups. In ${ }^{13} \mathrm{C}-\mathrm{NMR}$, a signal in $158.5 \mathrm{ppm}$ corresponding to the aromatic carbon linked to the $\mathrm{OH}$ group (C-2) is observed. In addition, three signals appear at 67.6; 67.3 and 25.6 ppm, assigned to the three methylene groups from the dioxane ring. In the mass spectrum was identified a peak with a value of 725.30 corresponding to the pseudomolecular ion $[\mathrm{M}+\mathrm{Na}]^{+}$.

Once the glycoside was obtained, the deprotection of the carbonyl group was accomplished. (Scheme 2).

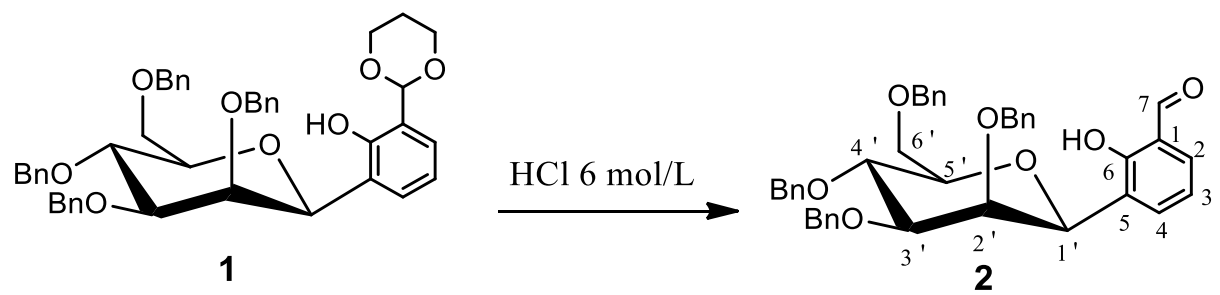

Scheme 2. Cleavage of dioxane ring in compound $\mathbf{1}$ to generate the compound $\mathbf{2}$.

The necessary drastic conditions $(\mathrm{HCl}, 6 \mathrm{~mol} / \mathrm{L})$ for the cleavage of dioxane ring justify the use of benzyl as a protecting group, since acetyl and/or benzoyl groups are hydrolyzed under these conditions. The achieved yield $(63 \%)$ demonstrates the stability of the $C$-glycosidic bond.

Compound 2 was obtained as a colorless syrup. In ${ }^{1} \mathrm{H}-\mathrm{NMR}$ spectrum, a singlet at 10.22 ppm was assigned to the aldehyde proton. The signal at $9.91 \mathrm{ppm}$ was assigned to the proton of the phenolic hydroxyl group. At $5.63 \mathrm{ppm}$ appears a doublet belonging to proton $\mathrm{H}-1$ ' of the sugar pyranose ring.

In the ${ }^{13} \mathrm{C}-\mathrm{NMR}$ spectrum, a signal appears at $188.9 \mathrm{ppm}$ corresponding to carbonyl carbon. COSY and HSQC experiments were performed to corroborate the assignment of the different signals. The HSQC evidences the correlation between the proton $\mathrm{H}-1^{\prime}$ and $\mathrm{C}-\mathrm{I}^{\prime}$ and the absence of $\mathrm{C} / \mathrm{H}$ correlation for the aromatic $\mathrm{C}-2$ linked to the $\mathrm{OH}$ group, confirming that this carbon does not couple with hydrogen atoms. In the mass spectrum was recorded a peak with a value of 667.26 corresponding to the pseudomolecular ion $[\mathrm{M}+\mathrm{Na}]^{+}$.

To obtain the glycosides of curcuminoids or chalcones, the condensation of the compound (2) was carried out with acetone and with acetylacetone (Scheme 3).

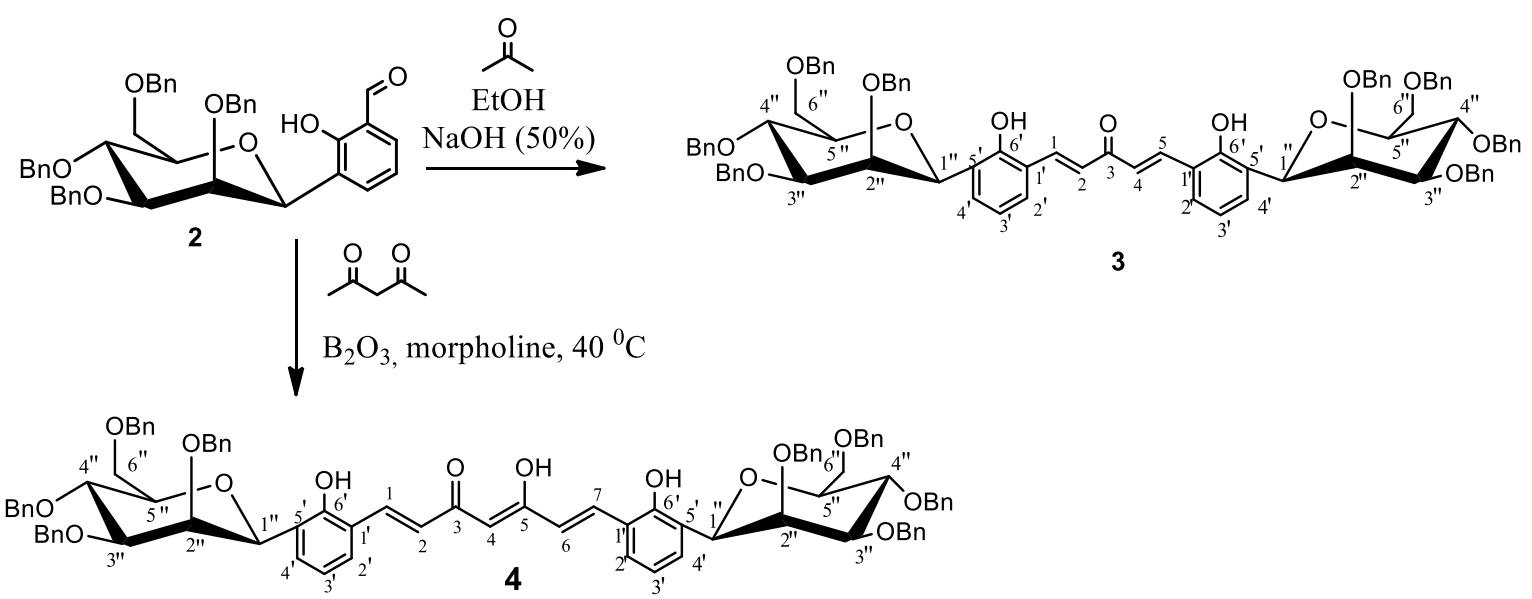

Scheme 3. Condensation of glycoside (2) with acetone and acetylacetone. 
For the condensation with acetone the following reaction conditions were used: aldehyde and acetone in 2:1 molar ratio, ethanol as solvent and $50 \% \mathrm{NaOH}$ as a catalyst. At first, the reagents were mixed at $0{ }^{\circ} \mathrm{C}$ and stirring was maintained for $5 \mathrm{~h}$. However, after this time remaining starting material was observed in the TLC. The reaction mixture was therefore stirred at room temperature for $12 \mathrm{~h}$. The product (3) was obtained in the form of a yellow syrup. Despite the structural complexity of the compound reflected in its NMR spectra, the symmetry of the molecule allows two characteristic signals of the chalcone (aglycone) to be observed on ${ }^{1} \mathrm{H}$ NMR: a singlet at $9.93 \mathrm{ppm}$, corresponding to the two groups $\mathrm{OH}$ phenolic, two doublets at 6.60 and $7.67 \mathrm{ppm}$ with ${ }^{3} J_{1.2}={ }^{3} J_{4.5}=16.6 \mathrm{~Hz}$ belonging to protons $\mathrm{H}-2, \mathrm{H}-4$ and $\mathrm{H}-1, \mathrm{H}-5$ belonging to the carbon chain of the chalcone. In the region between 7.10-7.40 ppm there is a high intensity multiplet assigned to the 40 aromatic protons of the benzyl groups, from 4.58 to $4.83 \mathrm{ppm}$ appear the characteristic multiplets of the eight methylene protons, between 3.80-3.67 ppm appears the multiplet belonging to the methylene group from mannose. At $5.50 \mathrm{ppm}$ a doublet corresponding to the vicinal coupling $\mathrm{H}-1$ ", $\mathrm{H}-2^{\text {" }}$ of the pyranose with ${ }^{3} \mathrm{~J}^{1 ", 22^{\prime \prime}}=$ $2.1 \mathrm{~Hz}$ is observed, which confirming the $\beta$ position of the aglycone.

In the ${ }^{13} \mathrm{C}-\mathrm{NMR}$ spectrum, the signal corresponding to the carbonyl group appears at $198.3 \mathrm{ppm}$, the signal of $\mathrm{C}^{-6}$ ' from the aglycone, directly linked to an $\mathrm{OH}$ group is observed at $154.9 \mathrm{ppm}$, in the region between 127.7 and $128.5 \mathrm{ppm}$ signals of the 40 aromatic carbon atoms of the benzyl groups are observed, the signals of the eight methylene from benzyl groups appear at 73.0; 73.3; 74.6 and 75.2 ppm respectively. On the other hand, the signal belonging to C-6" of the pyranose ring, appears at $68.9 \mathrm{ppm}$. The HSQC shows a correlation between $\mathrm{H}-1^{\prime} / \mathrm{C}-1^{\prime \prime}$ of pyranose ring from sugar and between $\mathrm{H}-1 / \mathrm{C}-1, \mathrm{H}-2 / \mathrm{C}-2 ; \mathrm{H}-4 / \mathrm{C}-4$ and $\mathrm{H}-5 / \mathrm{C}-5$ of the pentadienone unit confirming the assignment of the signals.

After the successful formation and characterization of the $C$-glycoside (3), the condensation of the aldehyde (2) with acetylacetone was attempted by microwave irradiation of the mixture. However, despite observing some evidence for the occurrence of the reaction such as fusion of the mixture and formation of an orange solid, typical in the process, TLC showed a series of products that could only be separated by subjecting the reaction mixture to two consecutive separations by chromatography. The yield of product (4) was $4 \%$.

To achieve greater efficiency, a modification of the technique reported by Pedersen et al. ${ }^{19}$ using DMF as a solvent, then the glycoside and the other reagents were added. The mixture was heated at $40{ }^{\circ} \mathrm{C}$ for $18 \mathrm{~h}$. After completion of the reaction, $20 \mathrm{~mL}$ of methanol was added and the mixture was sonicated for 30 minutes to break up the complex formed. After removing the solvent, the product (4) was purified by column chromatography, the compound was obtained as an orange syrup in a yield of $36 \%$.

In the ${ }^{1} \mathrm{H}$-NMR spectrum is observed a singlet at $15.89 \mathrm{ppm}$, corresponding to the hydroxyl proton of the enolic $\mathrm{OH}$ from the chalcone moiety and another singlet at $10.15 \mathrm{ppm}$ assigned to the protons of the two phenolic $\mathrm{OH}$ groups from the aromatic moiety of heptatrienone, which due to molecular symmetry appear as a single double intensity signal. Doublets at 6.48 and 7.85 ppm belonging to protons $\mathrm{H}-2, \mathrm{H}-6$ and $\mathrm{H}-1, \mathrm{H}-7$ of heptatrienone show similar value of the coupling constant ${ }^{3} J_{6,7}={ }^{3} J_{1,2}=16.1 \mathrm{~Hz}$, demonstrating the coupling between $\mathrm{H}-1 / \mathrm{H}-2$ and $\mathrm{H}-6 / \mathrm{H}-7$. At 4.83 ppm, the doublet corresponding to the vicinal coupling $\mathrm{H}-1^{\prime \prime}, \mathrm{H}-2^{\prime \prime}$ of the pyranose with ${ }^{3} J_{1,2^{\prime \prime}}=2.1 \mathrm{~Hz}$ appears, evidencing, as the previous cases, the $\beta$-position of the aglycone. The ${ }^{13} \mathrm{C}-\mathrm{NMR}$ spectrum shows the signals corresponding to the 87 carbon atoms of the molecule. At $183.3 \mathrm{ppm}$, the signal belonging to the carbonyl group appears, the signal at $155.1 \mathrm{ppm}$ of two quaternary carbon atoms, which are strongly deshielded, corresponds to the C-6' of the benzene rings from aromatic moiety of heptatrienone, directly linked to the $\mathrm{OH}$ group.

The DEPT spectrum shows five signals in: $68.9 ; 72.8 ; 73.0 ; 73.2 ; 74.8$ ppm, assigned to the ten methylene groups: two of them corresponding to the mannopyranose and the remaining belonging to the eight benzyl groups. Because the determination of the configuration of the anomeric carbon cannot be based solely on the 
vicinal coupling constant of $\mathrm{H}-1^{\prime \prime}$, a NOE experiment was performed in which interactions between $\mathrm{H}-\mathrm{1}^{\prime \prime}, \mathrm{H}-3^{\prime \prime}$ were observed, $\mathrm{H}-5^{\prime \prime}$ with the same intensity as the $\mathrm{H}-1$ " $/ \mathrm{H}-3$ " interaction, which confirms that the anomer obtained is indeed $\beta$-configurated. These results agree with those reported by Opatz et al. ${ }^{10}$ and allow us to confirm that the curcuminoid glycosides obtained exist in the $\beta$-form.

In the mass spectrum, the pseudomolecular ions $[\mathrm{M}+\mathrm{H}]^{+}$and $[\mathrm{M}+\mathrm{Na}]^{+}$are observed, with a mass increase of 1 and 23 units with respect to the calculated mass, these results together with the NMR data and elemental analysis, corroborate the proposed structure.

\section{Conclusions}

The use of tetra-O-benzyl-mannosyl trichloroacetimidate as a glycosyl donor and TMSOTf as a promoter, allowed us to achieve the glycosylation reaction with high $\beta$-selectivity, in which first an $O$-glycoside is formed, followed by an $O / C$ rearrangement. The drastic conditions of deprotection and condensation used require the use of benzyl as a protective group, due to its great stability in acid and basic media.

\section{Experimental Section}

The reagents and solvents used were of "pure" or "analytical" quality from Merck and Sigma-Aldrich. The reactions under the action of ultrasonic waves were developed in a Bandelin electronic device (RK 52), while the reactions developed under the action of microwaves were carried out in a multimode oven (EMC, model MDS-81D), equipped with pressure control and temperature. The course of the reactions was monitored by thin layer chromatography (TLC) in chromatographic plates (Al) of silica gel $60 \mathrm{~F} 254$ with $0.2 \mathrm{~mm}$ layer thickness (Merck). The plates were developed with mixtures of $5 \%$ sulfuric acid in $\mathrm{MeOH}$ and UV lamps (Type $\mathrm{NU}-8 \mathrm{KI}, \lambda: 254 \mathrm{~nm}$ ). For the isolation and purification of the products by column chromatography, silica gel 60 of $63-200 \mu \mathrm{m}$ (Merck) was used, columns of $20 \mathrm{~cm}$ in length and $1.5 \mathrm{~cm}$ in diameter were used. The solvent mixtures used as the mobile phase in $(\mathrm{v} / \mathrm{v})$ are referred to in each case. Specific optical rotations were determined in $2 \mathrm{~cm}$ cells with a GYROMAT automatic polarimeter (Dr. Kernchen Co.). The ${ }^{1} \mathrm{H}$ - NMR spectra $(250 ; 500 \mathrm{MHz})$ and ${ }^{13} \mathrm{C}-\mathrm{NMR}(75 ; 125.75 \mathrm{MHz})$ were obtained in $\mathrm{AC} 250$ and Avance 500 equipment at $20^{\circ} \mathrm{C}$. The chemical shifts $(\delta)$ are given in ppm and the coupling constants $(J)$ in $\mathrm{Hz}$. The signals in the ${ }^{13} \mathrm{C}$ spectra were assigned with the help of DEPT, two-dimensional COSY, HSQC and NOESY experiments. The mass spectra were recorded on an INTECTRA GmbH spectrometer, model (AMD-402/3), by electrospray ionization (ESI) and chemical ionization (IQ) with isobutane techniques. Elemental analysis was performed on Carlo Erba CHNS-O EA-1108 and Leco CHNS-932 equipment. 


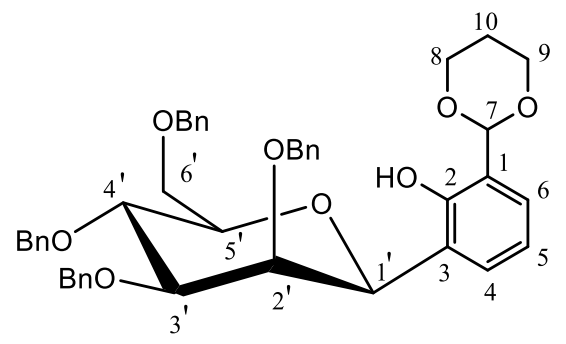

A mixture of tetra-O-benzylmannosyl trichloroacetimidate $(1.22 \mathrm{mmol}, 0.83 \mathrm{~g}), 2-(1,3-$ dioxan-2-yl)phenol (1.46 mmol, $0.26 \mathrm{~g})$ and activated molecular sieves $4 \AA$ (16 g) in anhydrous $\mathrm{CH}_{2} \mathrm{Cl}_{2}(128 \mathrm{~mL})$ was stirred at $0{ }^{\circ} \mathrm{C}$ for 20 min under an argon atmosphere. Then TMSOTf $1.22 \mathrm{mmol}(0.22 \mathrm{~mL})$ in anhydrous $\mathrm{CH}_{2} \mathrm{Cl}_{2}(2 \mathrm{~mL})$ was added and the mixture was stirred for $3 \mathrm{~h}$ according to the TLC. The reaction was stopped by the addition of a saturated $\mathrm{NaHCO}_{3}$ solution $(40 \mathrm{~mL}$ ). The organic phase was separated and the aqueous one was extracted with $\mathrm{CH}_{2} \mathrm{Cl}_{2}(50 \mathrm{~mL})$. The organic extracts were dried with $\left(\mathrm{Na}_{2} \mathrm{SO}_{4}\right)$ and after concentrating in vacuo the residue was purified by column chromatography (Petroleum ether-AcOEt 2: 1).

Colorless syrup ( $0.30 \mathrm{~g}, 36 \%$; fraction $8-16), R_{f}=0.23$ (Petroleum ether-AcOEt 2: 1 ), analytical sample of the $\beta$ anomer.

${ }^{1} \mathrm{H}-\mathrm{NMR}\left(\mathrm{CDCl}_{3}, 250 \mathrm{MHz}\right): \delta=2.19(\mathrm{~m}, 2 \mathrm{H}, \mathrm{H}-10) ; 3.62-3,43\left(\mathrm{~m}, 1 \mathrm{H}, \mathrm{H}-5^{\prime}\right) ; 3.87-3.64\left(\mathrm{~m}, 2 \mathrm{H}, \mathrm{H}-6^{\prime}\right) ; 3.92(\mathrm{dd}$, $\left.1 \mathrm{H}, \mathrm{H}-3^{\prime}, 3^{3} \mathrm{~J}^{\prime}, 3^{\prime}=2.0 ; 3^{3} \mathrm{~J}^{\prime}, 4^{\prime}=9.5 \mathrm{~Hz}\right) ; 3.98\left(\mathrm{~d}, 1 \mathrm{H}, \mathrm{H}-2^{\prime}, 3^{3} \mathrm{~J}^{\prime}, 3^{\prime}=2.0 \mathrm{~Hz}\right) ; 4.10(\mathrm{~m}, 4 \mathrm{H}, \mathrm{H}-8, \mathrm{H}-9) ; 4.26\left(\mathrm{t}, 1 \mathrm{H}, \mathrm{H}-4^{\prime}\right.$, $\left.{ }^{3} J_{3^{\prime}, 4^{\prime}} \approx 3^{3}{4^{\prime}, 5^{\prime}}^{\prime} \approx 9.5 \mathrm{~Hz}\right) ; 4.46\left(\mathrm{~d}, 2 \mathrm{H}, \mathrm{CH}_{2} \mathrm{Ph},{ }^{2} \mathrm{~J}=10.9 \mathrm{~Hz}\right) ; 4.55-4.79\left(\mathrm{~d}, 2 \mathrm{H} \times 4 \mathrm{CH}_{2} \mathrm{Ph}\right) ; 5.41\left(\mathrm{~d}, 1 \mathrm{H}, \mathrm{H}-1^{\prime}, 3^{3} 1_{1^{\prime}, 2^{\prime}}=\right.$ $2.1 \mathrm{~Hz}$ ); $6.87(\mathrm{~m}, 1 \mathrm{H}, \mathrm{H}-4) ; 6.94-7.24(\mathrm{~m}, 2 \mathrm{H}, \mathrm{Ar}-\mathrm{Bn}) ; 7.65\left(\mathrm{~d}, 1 \mathrm{H}, \mathrm{H}-6,{ }^{3} \mathrm{~J}_{5,6}=5.8 \mathrm{~Hz}\right) ; 7.40(\mathrm{~m}, 1 \mathrm{H}, \mathrm{H}-5) ; 10.06(\mathrm{~s}$, $1 \mathrm{H}, \mathrm{OH})$.

${ }^{13} \mathrm{C}-\mathrm{NMR}\left(\mathrm{CDCl}_{3}, 75.46 \mathrm{MHz}\right): \delta=25.6$ (C-10); 67.6 (C-8); 67.3 (C-9); 68.8 (C-6'); $73.0\left(\mathrm{CH}_{2} \mathrm{Ph}\right) ; 73.2\left(\mathrm{CH}_{2} \mathrm{Ph}\right)$; $74.4\left(\mathrm{CH}_{2} \mathrm{Ph}\right) ; 74.8$ (C-4'); $75.0\left(\mathrm{CH}_{2} \mathrm{Ph}\right) ; 75.0$ (C-2'); 79.1 (C-5'); 83.2 (C-3'); 96.9 (C-1'); 115.6 (C-4); 125.2 (C-6); 127.5 (C-3); 127.6 (C-5); 127.6; 127.9; 128.9; 128.0; 128.2; 128.3; 128.4; 128.7 (20C, Ar-Bn); 135.9 (C-1); 137.9; 138.0; 138.1; 138.2 (C x 4 ipsoPh); 158.5 (C-2).

MS: $\mathrm{M}\left(\mathrm{C}_{44} \mathrm{H}_{46} \mathrm{O}_{8}\right)$ calculated: 702.32 ; experimental $(\mathrm{M}+\mathrm{Na})^{+}: 725.308$

Synthesis of 3-(2',3',4',6'-tetra-O-benzyl- $\beta$-D-mannopyranosyl)-2-hydroxybenzaldehyde (2)

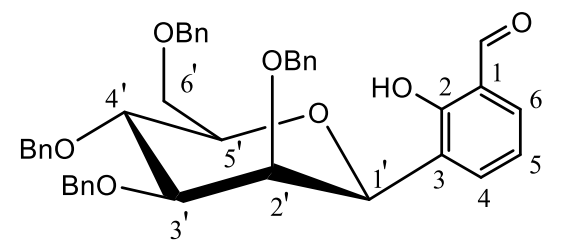

$0.95 \mathrm{mmol}(0.67 \mathrm{~g})$ of $(1)$ were dissolved in acetonitrile $(26 \mathrm{~mL}), 13 \mathrm{~mL}$ of $6 \mathrm{~mol} / \mathrm{L} \mathrm{HCl}$ was added and the mixture was refluxed for $1 \mathrm{~h}$. Then water $(50 \mathrm{~mL})$ was added, the excess acid was neutralized with saturated $\mathrm{NaHCO}_{3}$ solution, the mixture was extracted with $\mathrm{CHCl}_{3}(3 \times 30 \mathrm{~mL})$. The organic phase was dried with $\mathrm{Na}_{2} \mathrm{SO}_{4}$, concentrated and the product was purified by column chromatography (Petroleum ether-AcOEt 4: 1).

Colorless syrup (0.39 g, 63\%; fraction 4-12), $R_{f}=0.36$ (Petroleum ether-AcOEt 4: 1 ), analytical sample of the $\beta$ anomer.

${ }^{1} \mathrm{H}-\mathrm{NMR}\left(\mathrm{CDCl}_{3}, 250 \mathrm{MHz}\right): \delta=3.79-3.65\left(\mathrm{~m}, 1 \mathrm{H}, \mathrm{H}-5^{\prime}\right) ; 3.91-3.83\left(\mathrm{~m}, 2 \mathrm{H}, \mathrm{H}-6^{\prime}\right) ; 4.03\left(\mathrm{dd}, 1 \mathrm{H}, \mathrm{H}-3^{\prime}, 3^{3} \mathrm{~J}^{\prime}, 4^{\prime}=9.5 \mathrm{~Hz}\right.$, $\left.{ }^{3} J_{2^{\prime}, 3^{\prime}}=2.8 \mathrm{~Hz}\right) ; 4.07\left(\mathrm{~d}, 1 \mathrm{H}, \mathrm{H}-2^{\prime}, 3^{3} J_{2^{\prime}, 3^{\prime}}=2.1 \mathrm{~Hz}\right) ; 4.15\left(\mathrm{~d}, 1 \mathrm{H}, \mathrm{H}-4^{\prime}, J_{3^{\prime}, 4^{\prime}} \approx{ }^{3} J_{4^{\prime}, 5^{\prime}} \approx 9.5 \mathrm{~Hz}\right) ; 4.64-4.92(\mathrm{~d}, 2 \mathrm{H} \times 4$ 
$\left.\mathrm{CH}_{2} \mathrm{Ph}\right) ; 5.63\left(\mathrm{~d}, 1 \mathrm{H}, \mathrm{H}-1^{\prime},{ }^{3} J_{1^{\prime}, 2^{\prime}}=2.1 \mathrm{~Hz}\right) ; 7.09(\mathrm{~m}, 1 \mathrm{H}, \mathrm{H}-4) ; 7.44-7.14(\mathrm{~m}, 2 \mathrm{H}, \mathrm{Ar}-\mathrm{Bn}) ; 7.48(\mathrm{~m}, 1 \mathrm{H}, \mathrm{H}-5) ; 7.81$ (d, $\left.1 \mathrm{H}, \mathrm{H}-6,3 \mathrm{~J}_{5,6}=5.8 \mathrm{~Hz}\right) ; 9.91(\mathrm{~s}, 1 \mathrm{H}, \mathrm{OH}) ; 10.22(\mathrm{~s}, 1 \mathrm{H}, \mathrm{CHO})$.

${ }^{13} \mathrm{C}-\mathrm{NMR}\left(\mathrm{CDCl}_{3}, 75.46 \mathrm{MHz}\right): \delta=68.8\left(\mathrm{C}-6^{\prime}\right) ; 73.0\left(\mathrm{CH}_{2} \mathrm{Ph}\right) ; 73.2\left(\mathrm{CH}_{2} \mathrm{Ph}\right) ; 74.4\left(\mathrm{CH}_{2} \mathrm{Ph}\right) ; 74.8\left(\mathrm{C}-4^{\prime}\right) ; 75.0$ $\left(\mathrm{CH}_{2} \mathrm{Ph}\right.$ ); 75.0 (C-2'); 79.1 (C-5'); 83.2 (C-3'); 96.9 (C-1'); 115.6 (C-4); 125.2 (C-6); 127.5 (C-3); 127.6 (C-5); 127.6 ; 127.9; 128.9; 128.1; 128.2; 128.3; 128.5; 128.7 (20C, Ar-Bn); 137.9; 138.0; 138.1; 138.2(C x 4 ipsoPh); 158.5 (C2); $188.9(\mathrm{CHO})$.

MS: $\mathrm{M}\left(\mathrm{C}_{41} \mathrm{H}_{40} \mathrm{O}_{7}\right)$ calculated: 644.28; experimental $(\mathrm{M}+\mathrm{Na})^{+}: 667.26$

Synthesis of 1,5-bis-[6'-hydroxyphenyl-1'-(2',3',4',6'-tetra-O-benzyl- $\beta$-D-mannopyranosyl)]penta-1,4-dien-3one (3)

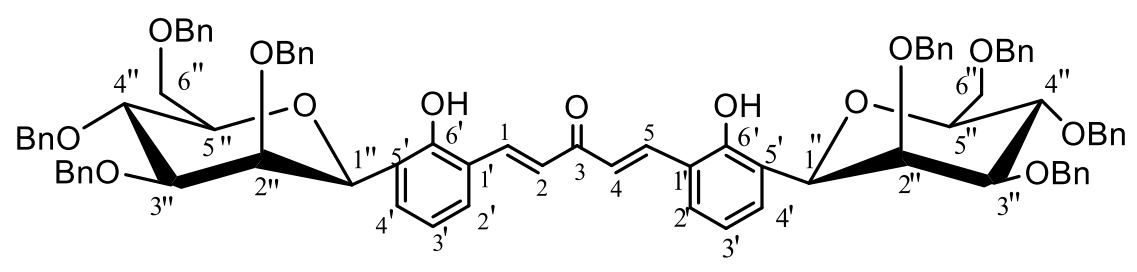

$0.6 \mathrm{mmol}(0.39 \mathrm{~g})$ of 2 were dissolved in $\mathrm{EtOH}(4 \mathrm{~mL}, 96 \%)$. After cooling the mixture to $0{ }^{\circ} \mathrm{C}, 0.3 \mathrm{~mL}$ of $\mathrm{NaOH}$ (50\%) was added with stirring, $0.22 \mathrm{~mL}$ of acetone $(0.3 \mathrm{mmol})$ was dripped and the mixture was stirred at 0-5 ${ }^{\circ} \mathrm{C}$ for $5 \mathrm{~h}$. The stirring was continued at room temperature for $18 \mathrm{~h}$. After adding water $(50 \mathrm{~mL})$, the orange color solution was neutralized with $\mathrm{HCl}(3 \mathrm{~mL}, 10 \%)$. The aqueous phase was extracted with $\mathrm{CHCl}_{3}(3 \times 50 \mathrm{~mL})$, dried with $\mathrm{Na}_{2} \mathrm{SO}_{4}$ and concentrated, the product was purified by column chromatography (Petroleum etherAcOEt).

Yellow syrup (0.23 g, 30\%; fraction 7-14); $[\alpha]=+9.0\left(\mathrm{c}=1.0 ; \mathrm{CH}_{2} \mathrm{Cl}_{2}\right) ; \mathrm{R}_{f}=0.35$ (EP-AcOEt 4: 1), analytical sample of the $\beta$-anomer.

${ }^{1} \mathrm{H}-\mathrm{NMR}\left(\mathrm{CDCl}_{3}, 500 \mathrm{MHz}\right): \delta=3.66-3.55\left(\mathrm{~m}, 2 \mathrm{H}, \mathrm{H}-5^{\prime \prime}\right) ; 3.80-3.67\left(\mathrm{~m}, 4 \mathrm{H}, \mathrm{H}-66^{\prime \prime}\right) ; 3.95$ (dd, $2 \mathrm{H}, \mathrm{H}-3^{\prime \prime}, 3^{3} 3^{\prime \prime}, 4^{\prime \prime}=9.1$ $\mathrm{Hz}, 3^{3} 2^{\prime \prime}, 3^{\prime \prime}=2.8 \mathrm{~Hz}$ ); 4.03 (d, $\left.2 \mathrm{H}, \mathrm{H}-2^{\prime \prime}, 3^{3} \mathrm{2}^{\prime \prime}, 3^{\prime \prime}=2.8 \mathrm{~Hz}\right) ; 4.08\left(\mathrm{~d}, 2 \mathrm{H}, \mathrm{H}-4^{\prime \prime}, 3^{3} 3^{\prime \prime}, 4^{\prime \prime} \approx 3^{3} \mathrm{~J}^{\prime}, 5^{\prime} \approx 9.1 \mathrm{~Hz}\right.$ ); $4.58-4.83$ (d, $4 \mathrm{H} \times 8 \mathrm{CH}_{2} \mathrm{Ph}$ ); 5.50 (d, $\left.2 \mathrm{H}, \mathrm{H}-1^{\prime \prime}, 3^{3} \mathrm{~J}^{\prime \prime}, 2^{\prime \prime}=2.1 \mathrm{~Hz}\right) ; 6.60\left(\mathrm{~d}, 2 \mathrm{H}, \mathrm{H}-2, \mathrm{H}-4,3^{3} \mathrm{~J}_{4,5}=16.6 \mathrm{~Hz}\right) ; 7.40-7.10(\mathrm{~m}, 40 \mathrm{H}, \mathrm{Ar}-$ $\mathrm{Bn}) ; 6,98\left(\mathrm{~m}, 2 \mathrm{H}, \mathrm{H}-3^{\prime}\right) ; 7.40-7.10(\mathrm{~m}, 40 \mathrm{H}, \mathrm{Ar}-\mathrm{Bn}) ; 7,32\left(\mathrm{~d}, 2 \mathrm{H}, \mathrm{H}-4^{\prime}, 3^{3} \mathrm{~J}^{\prime}, 4^{\prime}=6.2 \mathrm{~Hz}\right) ; 7,46\left(\mathrm{~d}, 2 \mathrm{H}, \mathrm{H}-2^{\prime}, 3^{3} \mathrm{z}^{\prime}, 3^{\prime}=6.2\right.$ $\mathrm{Hz}) ; 7.67\left(\mathrm{~d}, 2 \mathrm{H}, \mathrm{H}-1, \mathrm{H}-5,3^{3} \mathrm{~J}_{1,2}=16.6 \mathrm{~Hz}\right) ; 9.93(\mathrm{~s}, 2 \mathrm{H}, \mathrm{OH})$.

${ }^{13} \mathrm{C}-\mathrm{NMR}\left(\mathrm{CDCl}_{3}, 125.75 \mathrm{MHz}\right): \delta=68.9(\mathrm{C}-6 ") ; 72.6\left(\mathrm{CH}_{2} \mathrm{Ph} \times 2\right) ; 72.9\left(\mathrm{CH}_{2} \mathrm{Ph}\right) ; 73.0\left(\mathrm{CH}_{2} \mathrm{Ph} \times 2\right) ; 73.3(\mathrm{C}-4 ")$; $74.6\left(\mathrm{CH}_{2} \mathrm{Ph} \times 2\right) ; 75.2$ (C-2"); 80.2 (C-5"); 97.0 (C-3"); 115.5 (C-1"); 122.5 (C-4'); 123.9 (C-2, C-4); 124.0 (C-2'); 126.4 (C-5'); 127.7 (C-3'); 127.7; 127.7; 128.0; 128.2; 128.3; 128.4; 128.5; 131.8 (40C, Ar-Bn); 137.7 (C-1, C-5); 138.0(C-1'); 138.2; 138.2; 138.4; 138.5 (C x 8 ipsoPh); 154.9 (C-6'); 198.2 (C-3).

MS: $\mathrm{M}\left(\mathrm{C}_{85} \mathrm{H}_{82} \mathrm{O}_{13}\right)$ calculated: 1310.58 ; experimental $\left(\mathrm{M}^{+}\right)$: 1310.6 Elemental analysis: calculated \% C (77.84) \% $\mathrm{H}(6.30)$, found \% C (77.82) \% H (6.27).

Synthesis of 1,5-bis[-6'-hydroxyphenyl-1"-(2',3',4',6'-tetra-O-benzyl- $\beta$-D-mannopyranosyl)]-5-hydroxyhepta1,4,6-trien-3-one (4)

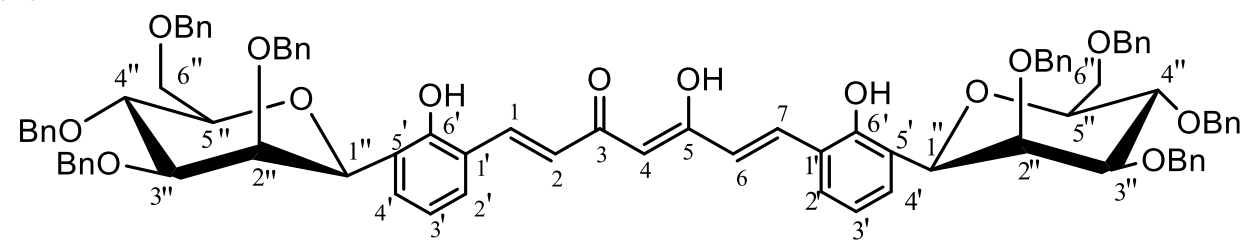


Acetylacetone $0.2 \mathrm{mmol}(0.20 \mathrm{~mL})$, boron oxide $0.2 \mathrm{mmol}(0.013 \mathrm{~g})$ and tributyl borate $3.7 \mathrm{mmol}(1 \mathrm{~mL})$ in 1.0 $\mathrm{mL}$ of DMF were mixed and the mixture was stirred at $65{ }^{\circ} \mathrm{C}$ for $15 \mathrm{~min}$. To the complex formed was added 3$\left(2^{\prime}, 3^{\prime}, 4^{\prime}, 6^{\prime}\right.$-tetra-O-benzyl- $\beta$-D-mannopyranosyl)-2-hydroxybenzaldehyde (2) (0.39 mmol, $\left.0.25 \mathrm{~g}\right)$ and the mixture was stirred for $5 \mathrm{~min}$. Subsequently, $10 \mu \mathrm{L}$ of morpholine was added and the mixture was stirred at 40 ${ }^{\circ} \mathrm{C}$ for $18 \mathrm{~h}$. After cooling to $25^{\circ} \mathrm{C}, 20 \mathrm{~mL}$ of $\mathrm{MeOH}$ was added and the orange solution obtained was subjected to ultrasound for $30 \mathrm{~min}$. After concentrating, the product was purified by column chromatography (EPAcOEt).

Orange syrup, $\left(0.18 \mathrm{~g}, 36 \%\right.$; fraction 5-10); $[\alpha]=-8.3\left(\mathrm{c}=1.0 ; \mathrm{CH}_{2} \mathrm{Cl}_{2}\right) ; \mathrm{R}_{f}=0.32$ (Petroleum ether-AcOEt 4: 1), analytical sample of the $\beta$-anomer.

${ }^{1} \mathrm{H}-\mathrm{NMR}\left(\mathrm{CDCl}_{3}, 500 \mathrm{MHz}\right): \delta=3.71-3.56\left(\mathrm{~m}, 2 \mathrm{H}, \mathrm{H}-5^{\prime \prime}\right) ; 3.85-3.72\left(\mathrm{~m}, 4 \mathrm{H}, \mathrm{H}-6^{\prime \prime}\right) ; 3.98\left(\mathrm{~d}, 2 \mathrm{H}, \mathrm{H}-3^{\prime \prime}, 3^{3} 3^{\prime \prime}, 4^{\prime \prime}=9.1\right.$

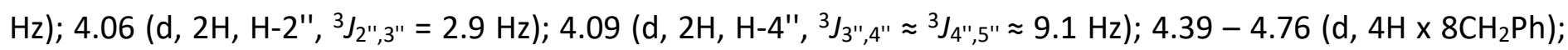
$4.83\left(\mathrm{~d}, 2 \mathrm{H}, \mathrm{H}-1^{\prime \prime}, 3^{3} \mathrm{I}^{\prime \prime}, 2^{\prime \prime}=2.1 \mathrm{~Hz}\right) ; 6.48\left(\mathrm{~d}, 2 \mathrm{H}, \mathrm{H}-2, \mathrm{H}-6,{ }^{3} J_{6,7}=16.1 \mathrm{~Hz}\right) ; 7.50-7.03(\mathrm{~m}, 40 \mathrm{H}, \mathrm{Ar}-\mathrm{Bn}) ; 7.48(\mathrm{~m}, 2 \mathrm{H}$, $\left.\mathrm{H}-3^{\prime}\right) ; 6.93\left(\mathrm{~m}, 2 \mathrm{H}, \mathrm{H}-4^{\prime}, 3^{3} \mathrm{~J}_{3^{\prime}, 4^{\prime}}=6.2 \mathrm{~Hz}\right) ; 7.73\left(\mathrm{~d}, 2 \mathrm{H}, \mathrm{H}-2^{\prime}, 3^{3} \mathrm{~J}_{2^{\prime}, 3^{\prime}}=6.2 \mathrm{~Hz}\right) ; 7.85\left(\mathrm{~d}, 2 \mathrm{H}, \mathrm{H}-1, \mathrm{H}-7,3^{3} \mathrm{~J}_{1,2}=16.1 \mathrm{~Hz}\right)$; $10.15(\mathrm{~s}, 2 \mathrm{H}, \mathrm{OH} \times 2) ; 15.89(\mathrm{~s}, 1 \mathrm{H}, \mathrm{OH})$.

${ }^{13} \mathrm{C}-\mathrm{NMR}\left(\mathrm{CDCl}_{3}, 125.75 \mathrm{MHz}\right): \delta=68.9\left(\mathrm{C}-6^{\prime \prime}\right) ; 72.8\left(\mathrm{CH}_{2} \mathrm{Ph} \times 2\right) ; 73.0\left(\mathrm{CH}_{2} \mathrm{Ph} \times 2\right) ; 73.0\left(\mathrm{CH}_{2} \mathrm{Ph} \times 2\right) ; 73.2(\mathrm{C}-4 ")$; 74.5 ( $\left.\mathrm{CH}_{2} \mathrm{Ph} \times 2\right)$; 74.8 (C-2"); 80.3 (C-5'); 97.0 (C-3"); 115.7 (C-1"); 122.4 (C-4'); 123.3 (C-2, C-6); 124.6 (C-2'); 126.4 (C-5'); 127.7 (C-3'); 127.7; 126.9; 127.9; 128.1; 128.2; 128.3; 128.3; 129.0 (C40, Ar-Bn); 136.7 (C-1, C-7); 138.0 (C-1'); 138.1, 138.2; 138.3; 138.3 (C x 8 ipsoPh); 155.1 (C-6'); 183.3 (C-3, C-5).

MS: $\mathrm{M}\left(\mathrm{C}_{87} \mathrm{H}_{84} \mathrm{O}_{14}\right)$ calculated: 1352.59 ; experimental $(\mathrm{M}+\mathrm{H})^{+}: 1353.59 ;(\mathrm{M}+\mathrm{Na})^{+}: 1375.57$

Elemental analysis: calculated \% C (77.20) \% H (6.25), found: \% C (77.45) \% H (6.52)

\section{Acknowledgements}

We would like to express our deep gratitude to the colleagues of the Institute of Chemistry of the University of Rostock in Germany for their collaboration in this work. Especially to Dr. Dirk Michalik for his help in the structural characterization of the obtained compounds.

\section{Supplementary Material}

The ${ }^{1} \mathrm{H}-\mathrm{NMR}$ spectra, ${ }^{13} \mathrm{C}-\mathrm{NMR}$ spectra and HRMS for title compounds 1-4 associated with this article are available as Supplementary data in the online version of the text.

\section{References}

1. Youssef, K. M.; El-Sherbeny, M. A.; El-Shafie, F. S.; Farag, H. A.; Al-Deeb, O. A.; Sit Albanat A. Awadalla, Arch. Pharm. Pharm. Med. Chem. 2004, 337, 42-54.

https://doi.org/10.1002/ardp.200300763

2. Amalraj, A.; Pius, A.; Gopi, S. JTCM. 2017, 7, 205-233.

https://doi.org/10.1016/i.jtcme.2016.05.005

3. He, Y.; Yue, Y.; Zheng, X.; Zhang, K.; Chen, S.; Du, Z. Molecules 2015, 20, 9183-9213.

https://doi.org/10.3390/molecules20059183. 
4. Pulido-Moran, M.; Moreno-Fernandez, J.; Ramirez-Tortosa, C.; Ramirez-Tortosa, M.C. Molecules 2016, 21,264, 2-22.

https://doi.org/10.3390/molecules21030264

5. Bililign, T.; Griffith B. R.; Thorson J. S. Nat. Prod. Rep. 2005, 22, 742-760. https://doi.org/10.1039/b407364a

6. Weatherman R. V.; Mortell K. I.; Chervenak, M.; Kiessling L. L.; Toone E. J. Biochemistry 1996, 35, 36193624.

https://doi.org/10.1021/bi951916z

7. Matsumoto, T.; Katsuki M.; Suzuki K. Tetrahedron Lett., 1988, 29, 6935-6938. https://doi.org/10.1016/S0040-4039(00)88479-8

8. Matsumoto, T.; Hosoya, T.; Suzuki, K. Synlett. 1991, 9, 709-711. https://doi.org/10.1055/s-1991-34769

9. Kometani T.; Kondo H.; Fujimori Y. Synthesis 1988, 1005-1007. https://doi.org/10.1055/s-1988-27788

10. Weck, S.; Opatz, T. Synthesis 2010, 14, 2393-2398. https://doi.org/10.1055/s-0029-1218772

11. Mydock-McGrane, L.; Cusumano, Z.; Han, Z.; Binkley, J.; Kostakioti, M.; Hannan, T.; Pinkner, J.; Klein, R.; Kalas, V.; Crowley, J.; Rath, N.; Hultgren, S.; JanetkaJ J. Med. Chem. 2016, 59, 9390-9408. https://doi.org/10.1021/acs.jmedchem.6b00948

12. Kitamura, K.; Ando,Y.; Matsumoto,T.; Suzuki; K. Chem. Rev. 2018, 118, 1495-1598. https://doi.org/10.1021/acs.chemrev.7b00380

13. Babak K. G.; Reza E.; Seradj H. Org. Lett. 1999; 1, 1737-1739. https://doi.org/10.1021/ol9909987

14. Ben, A.; Yamauchi, T.; Matsumoto, T.; Suzuki, K. Synlett 2004, 225-230. https://doi.org/10.1055/s-2003-44988

15. Li Y.; Wei G.; Yu B Carbohydr. Res. 2006; 34, 12717-2722. https://doi.org/10.1016/i.carres.2006.08.022

16. Mahling, J. A.; Schmidt R. R. Synthesis 1993, 325-328. https://doi.org/10.1055/s-1993-25859

17. Schmidt, R. R.; Michel, J. Angewandte. Chemie. 1980; 92, 763-764. https://doi.org/10.1002/ange.19800920933.

18. Karplus. M. J. Am. Chem. Soc. 1963, 85, 2870-2871. https://doi.org/10.1021/ja00901a059

19. Pedersen, U.; Rasrnussen, P. B.; Lawesson S. O. Liebigs Ann. Chem. 1985: 1557-1569. https://doi.org/10.1002/ilac.198519850805 